\title{
Students as promoters of rural extension in aquaculture in the Marajó archipelago, Pará, Brazil
}

\author{
Fabricio Nilo Lima da Silva ${ }_{5}^{1}$, Raoani Cruz Mendonça ${ }^{2}$, Manoel Luciano Aviz de Quadros ${ }^{3}$, Luã Caldas de Oliveira ${ }^{4}$, Antonia \\ Rafaela Gonçalves Macedo ${ }^{5}$, Osnan Lennon Lameira Silva ${ }^{6}$, Lenilton Alex de Araujo Oliveira \\ 1, 2, 3, 4 Instituto Federal de Educação, Ciência e Tecnologia do Pará - IFPA. Setor de Aquicultura do IFPA. Rua Antônio \\ Fulgêncio da Silva, s/n., Parque Universitário. Breves - PA. Brasil. ${ }^{5,6}$ Universidade Federal do Pará - UFPA. ${ }^{7}$ Instituto Federal \\ de Educação, Ciência e Tecnologia do Rio Grande do Norte - IFRN. \\ Author for correspondence: fabricio.nilo@ifpa.edu.br
}

\begin{abstract}
Aquaculture is the creation of aquatic organisms. An expanding activity, being of great importance its approach in rural extension. Thus, the objective of this study was to analyze the contribution of extension activities in aquaculture in the professional training of students in Marajó, Amazon, Brazil. The project "Technology transfer through training and technical assistance for tambaqui breeders, Colossoma macropomum, in the archipelago of Marajó/PA" was developed by 10 technician and under graduate students from rural education course and the technical course in aquaculture from the Federal Institute of Education, Science and Technology of Pará (IFPA) Campus Breves, in the city of Curralinho. They participated in the stages of data collection in aquaculture enterprises, training for producers and monitoring of aquaculture production, acting as researchers, instructors and extension workers, respectively. The duration of the project was from August 2019 to March 2020. At the end of the project, a questionnaire was applied to the students involved. The results showed that the aquaculture extension activities developed were relevant and significant, for the construction of knowledge in a mutual way between those involved (students and aquaculture producers). The acquired experiences will substantiate and subsidize the professional practice of these students in a concrete and effective way. In conclusion, the extension project represents an excellent tool in the teaching-learning process for students.
\end{abstract}

Keywords: Tambaqui, Experience, Teaching, Knowledge, Amazon.

\begin{tabular}{|l|l|l|l|l|l|l|} 
RBEC & Tocantinópolis/Brasil & v. 5 & e8936 & $10.20873 /$ uft.rbec.e8936 & 2020 & ISSN: 2525-4863 \\
\hline
\end{tabular}




\section{Estudiantes como promotores de la extensión rural en acuicultura en el archipiélago de Marajó, Pará, Brasil}

RESUMEN. La acuicultura es la creación de organismos acuáticos. Una actividad en expansión, su enfoque en la extensión rural es de gran importancia. Por lo tanto, el objetivo de este estudio fue analizar la contribución de las actividades de extensión acuícola a la formación profesional de los estudiantes en Marajó, Amazonia, Brasil. El proyecto "Transferencia de tecnología a través de capacitación y asistencia técnica para criadores de tambaqui, Colossoma macropomum, en el archipiélago de Marajó/PA" fue desarrollado por 10 estudiantes del Grado en Educación Rural y el Curso Técnico en Acuicultura del Instituto Federal de Campus de Educación, Ciencia y Tecnología de Pará (IFPA) Breves, en la ciudad de Curralinho. Participaron en las etapas de recolección de datos en empresas acuícolas, capacitación de productores y monitoreo de la producción acuícola, actuando como investigadores, instructores y extensionistas, respectivamente. La duración del proyecto fue de Agosto de 2019 a Marzo de 2020. Al final del proyecto, se aplicó un cuestionario a los estudiantes involucrados. Los resultados mostraron que las actividades de extensión de acuicultura desarrolladas fueron relevantes y significativas, para la construcción de conocimiento de manera mutua entre los involucrados (estudiantes y productores de acuicultura). Las experiencias adquiridas sustanciarán y subvencionarán la práctica profesional de estos estudiantes de manera concreta y efectiva. En conclusión, el proyecto de extensión representa una excelente herramienta en el proceso de enseñanza-aprendizaje para los estudiantes.

Palabras clave: Tambaqui, Experiencia, Enseñanza, Conocimiento, Amazonía. 


\section{Estudantes como promotores de extensão rural em aquicultura no arquipélago do Marajó, Pará, Brasil}

RESUMO. A aquicultura é a criação de organismos aquáticos. Uma atividade em expansão, sendo de grande importância sua abordagem na extensão rural. Assim, o objetivo desse estudo foi analisar a contribuição das atividades extensionistas em aquicultura na formação profissional de estudantes no Marajó, Amazônia, Brasil. O projeto "Transferência de tecnologia através da capacitação e assistência técnica para criadores de tambaqui, Colossoma macropomum, no arquipélago do Marajó/PA" foi desenvolvido por 10 estudantes do curso de Licenciatura em Educação do Campo e do curso Técnico em Aquicultura do Instituto Federal de Educação, Ciência e Tecnologia do Pará (IFPA) Campus Breves, na cidade de Curralinho. Eles participaram das etapas de coleta de dados nos empreendimentos aquícolas, capacitação aos produtores e acompanhamento da produção aquícola, atuando na condição de pesquisadores, instrutores e extensionistas, respectivamente. A duração do projeto foi de agosto de 2019 a março de 2020. Ao final do projeto, foi aplicado um questionário para os estudantes envolvidos. Os resultados mostraram que as atividades de extensão em aquicultura desenvolvidas foram relevantes e significativas, para a construção do conhecimento de maneira mútua entre os envolvidos (estudantes e produtores aquícolas). As experiências adquiridas irão fundamentar e subsidiar a prática profissional desses estudantes de forma concreta e efetiva. Em conclusão, o projeto de extensão representa uma excelente ferramenta no processo de ensino-aprendizagem para estudantes de Educação do Campo e de cursos técnicos em Aquicultura.

Palavras-chave: Tambaqui, Experiência, Ensino, Conhecimento, Amazônia. 
Silva, F. N. L., Mendonça, R. C., Quadros, M. L. A., Oliveira, L. C., Macedo, A. R. G., Silva, O. L. L., \& Oliveira, L. A. A. (2020). Students as promoters of rural extension in aquaculture in the Marajó archipelago, Pará, Brazil...

\section{Introduction}

Rural extension is considered one of the branches of Agrarian Sciences, which is configured through educational processes (Silva et al., 2018). It is conceived as a service for informal groups and collective organizations (Pizzio \& Milagres, 2018). It operates in the fields of agricultural, aquaculture and fisheries production, also in administration, food education, sanitary and ecological conditions, associations, cooperatives, solidarity economy and community action. Thus, it has been playing a fundamental role in the dissemination of knowledge and techniques for aquaculture (Karim et al., 2020; Joffre et al., 2020).

There are several studies focused on rural extension for aquaculture farmers (Oliveira et al., 2017; Obiero et al., 2019). They stand out in producing organisms with predominantly aquatic habitat. Thus, we can highlight fish farming (Silva, 2019), shrimp farming (Maciel \& Valenti, 2014), cheloniculture (Magnusson et al., 2003), raniculture (Stéfani et al., 2015), malacoculture (Lameira-Silva et al., 2020), among other aquaculture activities. These are important both from a social and economic point of view (Santiago \& SurísRegueiro, 2018), and are responsible for the continuous growth in the supply of fish to the world population (FAO, 2018).
In the northern region of Brazil, aquaculture is less developed compared to other regions of the country (IBGE, 2016). In the State of Pará, in the Eastern Amazon, the main activity is the fish farming. However, in this region, fish farming has faced several barriers, such as: the lack of credit (O 'de Almeida Júnior \& Souza, 2013); low training of labor (Oliveira et al., 2014); charging for water use (Tiago \& Gianesella, 2003); poor sanitary legislation and commercialization (Freire \& Gonçalves, 2013); enterprise management (Suplicy et al., 2015), high price and low quality of feed (Gonçalves et al., 2015) and scarcity and inefficiency of rural extension (Brabo et al., 2014). Such situations lead to failure in many aquaculture enterprises, including in the Marajó archipelago.

In this context, still stands out that Marajó has municipalities with low Human Development Indexes (HDI) (UNDP, IPEA, 2013). However, among its characteristics, it is worth mentioning the extensive hydrographic network, composed of basins, channels, meanders, lakes and streams, among which the Amazon, Pará, Anapu, Jacundá and Anajás rivers stand out (Crispim et al., 2016). Marajó has numerous affluent, which allow the practice of the culture of tambaqui, Colossoma macropomum, in 
Silva, F. N. L., Mendonça, R. C., Quadros, M. L. A., Oliveira, L. C., Macedo, A. R. G., Silva, O. L. L., \& Oliveira, L. A. A. (2020). Students as promoters of rural extension in aquaculture in the Marajo archipelago, Pará, Brazil...

several rural communities. This activity is important due to the continuous supply of fish to the local population. Aquaculture in the Amazon is rising, practiced by small and medium-sized producers, in addition to being exercised by family farming, extractivists and riverside dwellers.

In this context, to reduce the barriers in the aquaculture value chain, rural extension has fundamental importance, both for aquaculture farmers and students (Albuquerque et al., 2019). Thus, the path to the development of aquaculture must pass, firstly, through education (Under graduate, technical and professional) (Tubino, 2008; Silva \& Oliveira, 2020). According to Miter et al. (2008), the union between theory and practice, represents the breaking of educational paradigms, since it proposes a new view on teaching, in which it brings experience as something essential in learning. For this reason, aquaculture extension projects are needed in educational institutions (Dutra et al., 2015).

Thus, students involved in extension projects, become professionals able to work in the aquaculture branch, either as entrepreneurs, in technical consultancy, in aid to research and extension and/or in public agencies in the area. It is worth mentioning that studies of experiences in extension projects have been reported in several areas of knowledge (Fadel et al., 2013; Martins et al., 2015; Silva et al., 2019). These highlight the purpose of strengthening contextualized teaching. Given the above, the objective of the study was to report the contribution of extension activities in aquaculture in the professional training of students in the Marajó archipelago, state of Pará, Amazon region, Brazil.

\section{Material and methods Study area}

The aquaculture extension project was carried out in the municipality of Curralinho, in the Marajó archipelago, Pará, Brazil (Figure 1). Marajó is located on the Amazon coast (Amaral et al., 2012). Region composited by 16 municipalities, which comprise the Arari microregions (Cachoeira do Arari, Chaves, Muaná, Ponta de Pedras, Salvaterra, Santa Cruz do Arari and Soure), Furos de Breves (Afuá, Anajás, Breves, Curralinho and São Sebastião da Boa Vista) and Portel (Bagre, Gurupá, Melgaço and Portel). Curralinho has a territorial extension of $3,620,279$ $\mathrm{km} 2$, its population is estimated at 33,893 people for 2018 (IBGE, 2010). Most of this population lives in the riverside, due to the city being surrounded by rivers and islands, especially fishermen, extractivists, aquaculture and family farmers. 
Figure 1 - Location of the study area, indicating: a) municipality of Curralinho, Marajó, Pará, Brazil; b), c) and d) students in extension activities.
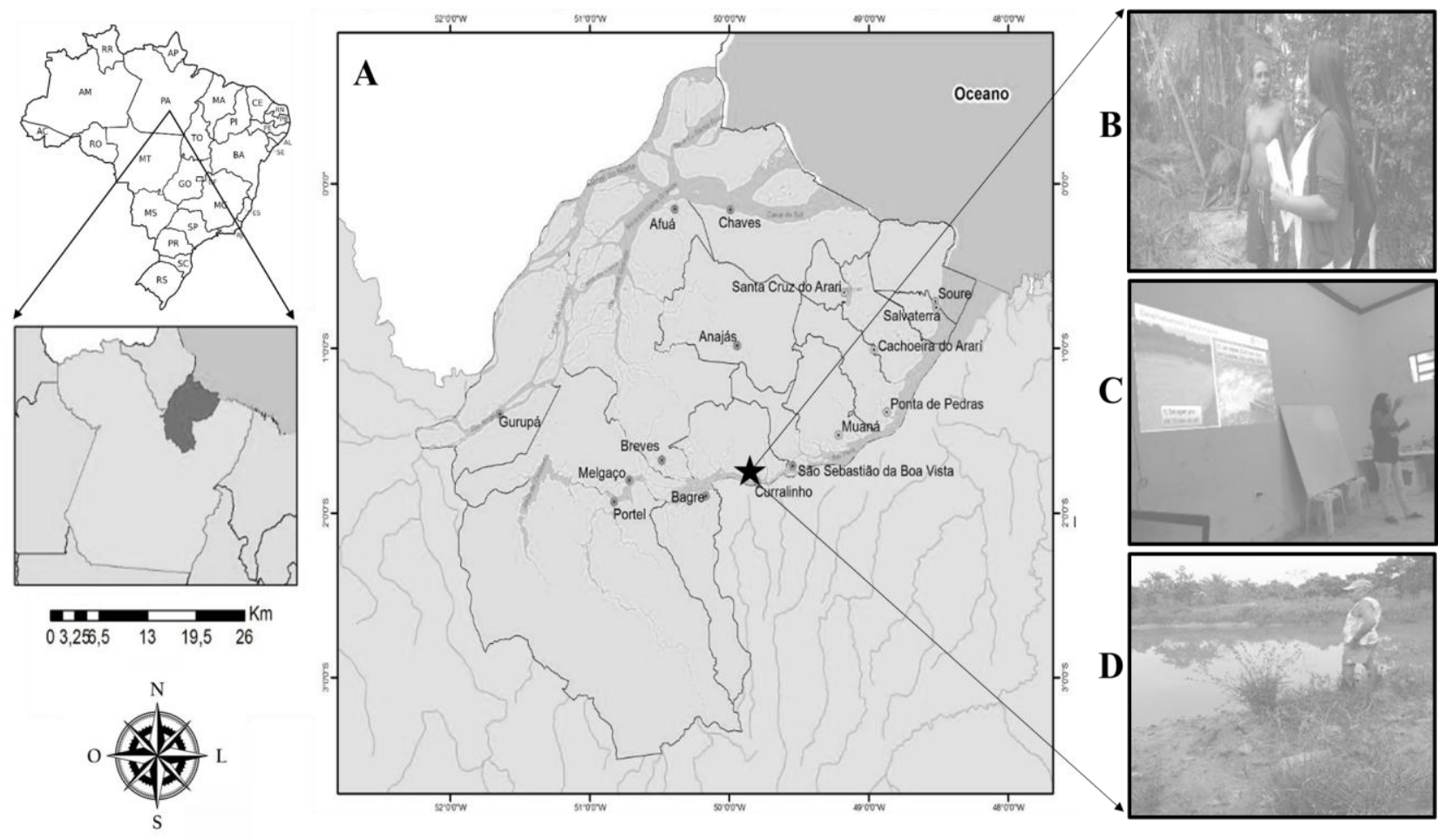

Source: Prepared by Fabricio Silva.

\section{Aquaculture experience report}

The project "Technology transfer through training and technical assistance for creators of tambaqui, Colossoma macropomum in the archipelago of Marajó/PA" was funded by the Dean of Extension and External Relations (PROEX) of the Federal Institute of Education, Science and Technology of the Pará (IFPA), under notice number 03/2019. The project was called "Piscicultura Marajoara", being conducted by 10 students regularly enrolled in under graduate course in Rural Education and the
Technical course in Aquaculture at the IFPA Campus Breves. The students received financial support for the acquisition of materials necessary for their execution, as well as the provision of extension scholarships. They participated in all stages of the project, such as: data collection in fish farms (check list), training aquaculture farmers and monitoring the production of tambaqui in rural communities, acting as researchers, instructors and extension workers, respectively. The duration of the project was from August 2019 to March 2020. 
Silva, F. N. L., Mendonça, R. C., Quadros, M. L. A., Oliveira, L. C., Macedo, A. R. G., Silva, O. L. L., \& Oliveira, L. A. A. (2020). Students as promoters of rural extension in aquaculture in the Marajo archipelago, Pará, Brazil...

At the end of the project, a structured interview was conducted with students participating in the project, adapted from Rodrigues et al. (2012). Extension experiences in aquaculture were treated in the student's training, allowing for a reconstruction of knowledge, in which experience is the center. It was possible to understand, from the student's point of view, how knowledge construction proceeds from experiences with the extension project involved. It was possible to analyze the impact of extension activities on the students' trajectory, considering that the project favors the exchange between those involved and their different experiences in extension, stimulating the emergence of collective discussions in varied experiences, bringing a set of diverse information (Silva, 2019).

During the interview, they were asked: a) what could you say about the aquaculture extension project in Marajó? b) what led you to become interested/engage in the extension project? c) talk a little about how is your routine in rural extension activities, d) was there any change in your school life, from the moment you got involved in extension activities? Can you give any example? e) In terms of training, what experience does the aquaculture extension project influence/influenced in your school life?
How do you perceive the relationship between these experiences and your course? Exemplify and f) from your experiences, what relationships can be observed among extension, teaching and research? What do you understand about this statement?

It was possible to carry out socialization (conversation circle) between teachers and students involved in the extension project. The students were invited to debate, on the various themes related to the extension project and their experiences in rural extension. In this activity, the teacher takes on the role of mediator of discussions (Silva et al., 2019). This work is qualitative and was approved by the Research Ethics Committee with Human Beings (CEP) of the Institute of Health Sciences of the Federal University of Pará (UFPA), registration number 2.576.907. The speech analysis methodology was used in this study. Therefore, the reports obtained were analyzed and discussed with support from the scientific literature.

\section{Results and discussion}

In the present study, among the students participating in the project, $30 \%$ were male and $70 \%$ female. The age of the interviewees ranged between 24 and 37 years. All students participating in the 
project are from Pará, born in Marajó, distributed among the municipalities of Breves, Curralinho and Melgaço. IFPA Campus Breves is a renowned institution in Marajó that, since its foundation, has served students from different municipalities, especially in its coverage area (Ordinance No. 017/2013 CONSUP), promotes professional and technological education, through teaching, research and extension, articulating knowledge and socio-cultural diversity to form citizens committed to the sustainable development of Marajó.

We realized the importance of students involved at aquaculture extension projects in Marajó, which is evidenced in the statements of some extension workers:

... The extension project is extremely important to meet the needs of fish farmers in a region that has great potential in the aquaculture sector. But, which is still very lacking in technical guidance and the project came to add knowledge and practices with the tambaqui producers ... (Student of the Technical course in Aquaculture).

... The Piscicultura Marajoara project is undoubtedly something of great importance for families living in the rural areas. Because through it we can have access to information that will benefit our properties, thus opening up a range of opportunities for fish farmers to be able to develop their activities without suffering many losses in their production. It aims to clarify any and all existing doubts, so that fish farmers can develop a fish culture on their properties that does not degrade the environment ... (Under Graduate Student of Rural Education).

... It is an excellent idea to bring knowledge to fish farmers in our riverside regions ... (Student of the Technical course in Aquaculture).

Volpato et al. (2016) emphasize that student participation in extension projects contributes for training and is configured as a way to improve qualification. In this study, students experienced the real problems of society, including the aquaculture activity in Marajó. Albuquerque et al. (2019) also described that the interaction between university and society was also experienced by students of the Aquaculture Engineering course at the Federal University of Grande Dourados (UFGD), in the city of Dourados in the state of Mato Grosso do Sul. They highlighted the importance of aquaculture, in promoting knowledge sharing through interpersonal relationships and interaction with all aquaculture farmers.

Created in 2008 by Law 11,892, the Federal Institutes of Education have as one of their purposes the development of extension, scientific and technological dissemination programs (Brasil, 2008). IFPA is linked to the Federal Education Network and the Ministry of Education, endowed with administrative, patrimonial, financial, didactic, pedagogical and disciplinary autonomy. Among the various 
campuses in the territory of Pará, the Campus Breves, throughout its history, presents a continuous evolution that accompanies and contributes to the development process of Marajó, in the Brazilian Amazon.

With regard to the opinions of students regarding the extension project in aquaculture, all agree that such activities were necessary in the educational field. The project is seen as an integrating curricular component for undergraduate and technical courses, of paramount importance for the area of knowledge and the contents that were taught, and practiced during the execution of the action. For Rosário et al. (2013), students get closer to society and have the opportunity to experience the application of knowledge of their future profession, thus being able to identify aspects that need to be improved to expand their professional competence.

According to the speech of two students in the aquaculture extension project:

... The Piscicultura Marajoara project is a project that came to contribute not only for us as students, but mainly for the fish farmers who came to participate in the training, because, through the information they received they will put into practice, so they will be looking for favorable conditions for better development of your fish culture and as a result, strengthening the municipality's production chain ... (Student of the Technical course in Aquaculture).
... It was a project that brought the opportunity to clarify some doubts for small fish farmers to improve their productivity and also for students of the technical course in aquaculture to develop a work in practice thus preparing them to work in the area ... (Student of the Technical course in Aquaculture).

We observed that in the statements above, the subjects understand the aquaculture extension project as the practice of the knowledge acquired at the Institute. The presented context dialogues significantly with the educational ideas of Freire (2001), in the defense of a critical education, at the service of social, economic and political transformations, aiming at overcoming social inequalities, called pedagogy of problematization. This mobilizes and stimulates the subject's autonomy, the dialogical relationship between teacher and students, the democratic social relationship that promotes the construction of knowledge (Sonzogno et al., 2013). Fish farming is understood as an agricultural activity (Garutti, 2003) and necessary theme in technical courses in Aquaculture. Thus, it is inserted among the competences of these professionals, which is provided for in Resolution $\mathrm{n}^{\circ}$ 4, of December 8, 1999 of the Basic Education Chamber of the National Education Council (CEB/CNE, 1999). It is worth mentioning that it is also 
of paramount importance in the Degree at Rural Education, especially in the area of aquaculture. The students demonstrated that the aquaculture extension project was important both for the basic knowledge of technicians and graduates in Rural Education and for the professional performance of the technician, which corroborates the recommendation of the Resolution mentioned.

When asked about what led them to become interested in/engaged in the extension project, many students were emphatic in mentioning the search to further deepen their knowledge in the area of aquaculture, but what caught the attention was what some students from the technical courses in aquaculture and rural education said. For them, the most important was the opportunity to acquire and improve technical knowledge, through theoretical and practical classes on fish farming and how much it will be useful for students and local producers:

... What interested me was the opportunity to acquire technical knowledge that will collaborate with the technical course in Aquaculture, in addition to the interest in being able to help producers in our region ... (Student of the Technical course in Aquaculture).

... What made me interested in the project was that I saw an opportunity to further improve my knowledge, and to learn a little more about fish farming and its various forms of work, as a future teacher in the field, the project gives me the opportunity to develop strategies to work with my future students ... (Under graduate Student in Rural Education).

... What got me interested in the project was its methodology (carrying out the training), its objective and the opportunity to pass on to fish farmers what we learned in theoretical and practical classes ... (Student of the Technical course in Aquaculture).

In the present study, the students stated that the fish farming extension project is the own extension from the discipline to the community. There are different ways of conceiving education, inside and outside educational institutions. Pedrosa (2007) criticizes the positivist conception, talking about popular education, in which there is a political formation of the subjects (critics, actors and transformers of their context).

The contents that are taught in the classroom came from experiences carried out in communities, where a certain phenomenon that was studied (diagnosis of aquaculture) was identified, in which the results were applied at the Institute (teaching) and disseminated to the communities (extension). A strong point of the extension is that there is the emergence of a movement (dynamics), in which the diagnosis obtains new results that are disseminated through teaching and 
Silva, F. N. L., Mendonça, R. C., Quadros, M. L. A., Oliveira, L. C., Macedo, A. R. G., Silva, O. L. L., \& Oliveira, L. A. A. (2020). Students as promoters of rural extension in aquaculture in the Marajó archipelago, Pará, Brazil...

disseminated through extension (Mendes, 2010).

When asked about their routines in rural extension activities in aquaculture, the fellows and volunteers pointed out that they had to prepare in advance, studying hard and preparing the slides on the subjects that would be taught in the training in addition to all the planning for visits to the properties for the application of the checklist:

... Since the beginning of the project, when I applied the check list, I had to change several routines in my life, as well as preparing the slides and the two days of training ... (Student of the Technical course in Aquaculture).

... My routine is of studies and research, absorbing as much knowledge as possible, and when they call my help, I will be ready to help them. It was also a routine trip, hiking and cycling in search of fish farmers through the check list ... (Student of the Technical course in Aquaculture).

The relationship between the curricular component and the aquaculture extension project is identified by the students. Specifically in these data, we were able to understand that there is still a practice of extension that can be seen as assistentialist work and that the transmission of knowledge occurs through technicist methods. It is clear that learning is not restricted to technical knowledge, as students are close to reality, demonstrating motivation in carrying out activities and living with farming families and colleagues, experiencing a collective experience of knowledge exchange.

In the present study, it was raised with the students if there was any change in their personal and student life within the Institute, from the moment they became involved in extension activities. In view of this, some students stated that they underwent a personal change seeing the deficiencies of public policies in favor of a class as needy as aquaculture farmers. They saw more clearly the social, environmental and economic impacts of these activities without due care and aroused the desire to develop new projects and works that aim to benefit these social actors:

... Yes, from the extension project, several ideas emerged to carry out other projects that benefit producers and give more visibility to our local products, for this we intend to organize together with some entities of the municipality the fish fair in Curralinho ... (Student of the Technical course in Aquaculture).

... Yes, there were several changes, as research on fish farming in this project only contributed to my development as a person and also as a teacher in training. After contacting fish farmers, they hear about their experiences, and also about the great challenges that are faced in order to develop fish farming, without the support of public policies aimed at these products. Through the development of the project, I was 
Silva, F. N. L., Mendonça, R. C., Quadros, M. L. A., Oliveira, L. C., Macedo, A. R. G., Silva, O. L. L., \& Oliveira, L. A. A. (2020). Students as promoters of rural extension in aquaculture in the Marajó archipelago, Pará, Brazil...

awakened to learn a little more about the different ways that fish farming is developed and how it can generate social, environmental and economic impacts. I also learned how to develop low cost technologies, about the importance of developing step by step of each process so that the production will generate a lot of profits and less loss, however after the completion of the project I can share my experience within my class talking about how important it is to invest in projects that benefit family farmers and workers ... (Under graduate Student in Rural Education).

...Yes, there were many changes mainly in terms of knowledge, and when I was able to engage in this extension project, I met new techniques for dealing with research, seminars and working with the public, that is, people ... (Student of the Technical course in Aquaculture).

With the interaction between IFPA and the community, the subject becomes aware of the context in which he is inserted, encouraging him to be more participative. He captures significant knowledge for his place of experience, expanding his critical and reflective view on the determinants of the production chain of fish farming in Marajó. Extension in Brazilian institutions is one of the ways to develop a complete academic education, which integrates theory and practice in communication with society and enables an exchange of knowledge between both (Manchur et al., 2013).

The student's contact with the professional environment and with the agents that compose it (aquaculture farmers), stimulated the exchange of knowledge and experiences, for all who participated in these activities, such as, for example, the dialogue about the tambaqui fish production chain, as well as structures for the breeding and marketing of farmed fish. Dutra et al. (2015) highlights that it is necessary to integrate aquaculture knowledge with the shortage and needs of society, through the exchange of knowledge between students, teachers and aquaculture farmers.

The participation in the fish farming extension project, through the relationship between practical experiences and training, influenced the lives of these students, awakening in them a feeling of better professionals, well qualified and attentive to the demands and needs of the local community, as is evident in some of the lines:

... In terms of training, I can say that it is an experience that influenced my development where I was able to learn various techniques, which will add to the technical course in aquaculture. I see this relationship as extremely important for us to be a well qualified professional in the future ... (Student of the Technical course in Aquaculture).

... Participation in the project, influenced me to want to participate in more projects, because they only have to contribute to our training. Contributing to these projects makes us different, questioning people, 
Silva, F. N. L., Mendonça, R. C., Quadros, M. L. A., Oliveira, L. C., Macedo, A. R. G., Silva, O. L. L., \& Oliveira, L. A. A. (2020). Students as promoters of rural extension in aquaculture in the Marajó archipelago, Pará, Brazil...

always seeking the well-being of the population in general. It is worth mentioning that this project contributed in a huge way to my training and to my undergraduate course in general, because it showed me the various themes that must be addressed in fish farming and how much it can benefit a population that is thus prevented, the flow migration of people from their localities to the city, being able to develop in their communities sustainable and lowcost work whose central objective is to expand the life of the small producer ... (Under Graduate Student in Rural Education).

... A better understanding of the subjects, due to having studied the subjects a lot, I was able to better absorb the information that I did not understand during the classes in the classroom ... (Student of the Technical course in Aquaculture).

... Participating in the project was very rewarding, but it was also achieving our goal, which was to train those fish farmers, it was an incredible experience, where I was able to learn at the time of each presentation by colleagues and exchanges of dialogues. From this lived experience, I feel safer to perform any other activity that my training requires, because, I came to understand better that the more you study about the subject, the more dominance you have over it, so there will be no improvisation of words that may harm the approach to the topic ... (Student of the Technical course in Aquaculture).

In the present study, students were asked about the importance of teaching, research and extension based on the experiences they had in this project. The group emphasized the non-dissociability among research-teaching-extension, understanding that the fish farming extension project in Marajó was a collective work. The group understands as an opportunity to add value, knowledge and other possibilities to strengthen the professional side, in addition, they affirmed that teaching brings guidance, research identifies problems and proposes solutions and the extension is the practical execution of what is learned and thought of as is clear in some of the students' statements:

... The extension aims to bring knowledge to small producers, the teaching guides us and the research look for something new for the community in general ... (Student of the Technical course in Aquaculture).

... The existing relationship between extension, teaching, and research is a diversified one, the three when together can contribute in a great way to the development of both the student and the coordinators and project directors, providing so a source of inexhaustible knowledge that will bring countless benefits both for the institution that works these three axes and for the student who is available to participate in the same ... (Under Graduate Student in Rural Education).

... A relationship of seeking knowledge through research, studies and taking projects to fish farmers. I can say that we need to go in search of knowledge before the research, in order to bring knowledge to the local producers. Example: How to manage water quality ... (Student of the Technical course in Aquaculture).

... What I could observe about extension, teaching and research 
Silva, F. N. L., Mendonça, R. C., Quadros, M. L. A., Oliveira, L. C., Macedo, A. R. G., Silva, O. L. L., \& Oliveira, L. A. A. (2020). Students as promoters of rural extension in aquaculture in the Marajo archipelago, Pará, Brazil...

were that, they seem to be distant words, but when we refer to a project, they are interconnected, one makes sense to the other, through research, knowledge is acquired (teaching) to be passed on in an extension way, so that I can reach as many people as possible from my target audience ... (Student of the Technical course in Aquaculture).

The talks shows the duty of teaching, transmit the knowledge acquired in the educational environment and enter it in society. In order for this knowledge to be transmitted, one must have a good knowledge of the message to be processed and understand the context in which the recipient is inserted, so that the transcription of the message is correctly transformed into necessary and real information. The school unit not only has the function of making the pedagogical process attractive and challenging, in order to promote intellectual, social, affective progress, but it must also be a democratic, reliable and culturally rich space, inserted in the socio-cultural context (Ferretti et al., 2004).

It is evident in this study that the activities carried out during the aquaculture extension project period were extremely important for the professional training of students, as it made it possible to study school content. The project incorporated fundamental elements for the foundation of professional training, that is didactic aspects of rural extension for local development and an educational and communicational approach.

The training of a professional in the field of agrarian sciences that is in accordance with the principles of the School/Institute/University cannot occur in a fragmented and discontinuous way. The valorization of extension practice as a fundamental part of training, assumes the idea that subjects enter a technical and higher education institution to have access to knowledge, and that teachers are responsible for transmitting it during practice because they have this knowledge as noted in that study.

In the present study, we perceive that the exchange of knowledge between IFPA Campus Breves students with communities, integrates various areas of knowledge and social sectors, determines a holistic view of the local reality. Therefore, the study in rural communities makes the student perform tasks such as: diagnosis (check list), booklets, organization for training, rural extension, preparation of reports, among others. This promotes the development of skills that support their training and obtaining information, helping their educational and aquaculture practices.

Besides that the interventions carried out by students in the extension project in aquaculture, promoted the selfmanagement of fish farms, respecting their 
Silva, F. N. L., Mendonça, R. C., Quadros, M. L. A., Oliveira, L. C., Macedo, A. R. G., Silva, O. L. L., \& Oliveira, L. A. A. (2020). Students as promoters of rural extension in aquaculture in the Marajo archipelago, Pará, Brazil...

forms of organization and tacit knowledge, which becomes essential for reflection and operationalization in the planning of teaching, research and practical procedures. Thus, it has been shown to be an important tool for learning, especially for the areas of aquaculture, among other areas of knowledge.

With regard to the importance of the aquaculture extension project in the training of students, we can conclude that the extension provided knowledge that will positively modify the way of performing fish farming in the community, as observed in these two statements:

... From the extension of an educational project, quality education for low-income people comes, and around all of this, there was a research for this project to be carried out ... (Student of the Technical course in Aquaculture).

... The project is very important because, through it, techniques unknown to producers were passed on that can maximize production without posing a high risk to the environment ... (Student of the Technical course in Aquaculture).

The training of a professional in the area of aquaculture that in accordance with the principles of the IFPA Campus Breves cannot occur in a random and imprecise manner. Therefore, must have value the extension practice as a key part of training, taking the idea that subjects enter into an educational institution to have access to the knowledge and teachers are responsible for transmitting during practice as evidenced in that study.

\section{Conclusion}

According to the students' view, participation in the aquaculture extension project in Marajó, further intensified the knowledge acquired in the classroom. It showed that the interest in being part of the project arose from the need to become multipliers of knowledge in aquaculture. These students had to greatly modify their school routines to be able to exceed the objectives proposed by the project. They became people with a different view of the social, environmental and economic needs of a community that is poor assisted by public policies. As main experiences, many students see themselves as promoting agents of rural extension in aquaculture and that for them the educational institution was able to actually fulfill its role in society, with the exception of teaching, research and extension practices together in aquaculture as an inseparable tripod.

\section{Acknowledgements}

To the Dean of Extension (PROEX) of the Federal Institute of Education, Science and Technology of Pará (IFPA), for the research funding (Notice no. 
Silva, F. N. L., Mendonça, R. C., Quadros, M. L. A., Oliveira, L. C., Macedo, A. R. G., Silva, O. L. L., \& Oliveira, L. A. A. (2020). Students as promoters of rural extension in aquaculture in the Marajó archipelago, Pará, Brazil...

03/2019). To the Municipality of Curralinho and Z-37 fishermen colony, for the structural support in the activities. The under graduate students in Rural Education and of the technical course in Aquaculture for them contribution to the study.

\section{References}

Albuquerque, D. M., Herrig, E. A., \& Cavichiolo, F. (2019). Aquicultura como ferramenta de interação entre Universidade e Sociedade. Revista online de Extensão e Cultura, 6(12), 36-43. https://doi.org/10.30612/reufgd.v6i12.10553

Amaral, D. D., Mantelli L, R., \& Rossetti, D. F. (2012). Paleoenvironmental control on modern forest composition of southwestern Marajo Island, Eastern Amazonia. Water and Environment Journal, 26, 70-84. https://doi.org/10.1111/j.1747$\underline{6593.2011 .00265 . x}$

Brabo, M. F. (2014). Piscicultura no estado do Pará: situação atual e perspectivas. Revista Actapesca, 2(1), i-vii. https://doi.org/10.2312/Actafish.2014.2.1.i -vii

Brasil. (2008). Lei no 11.892/08, de 29 de dezembro de 2008. Institui a Rede Federal de Educação Profissional, Científica e Tecnológica, cria os Institutos Federais de Educação, Ciência e Tecnologia, e dá outras providências. Brasília, Diário Oficial [da] União, 2008. Retrieved: http://www.planalto.gov.br/ccivil_03/_Ato 2007-2010/2008/Lei/L11892.htm. Access in: 06/04/2020.

CEB/CNE. (1999). Câmara de Educação Básica do Conselho Nacional de Educação. Resolução CEB No 4, de 8 de dezembro de
1999. Institui as Diretrizes Curriculares Nacionais para a Educação Profissional de Nível Técnico. Diário Oficial [da] União, Conselho Nacional de Educação, Brasília, DF, 22 dez. 1999. Retrieved: http://portal.mec.gov.br/setec/arquivos/pdf/ resol0499.pdf. Access in: 06/04/2020.

Crispim, D. L., Rodrigues, R. S. S., Vieira, A. S. A., Silveira, R. N. P. O., \& Fernandes, L. L. (2016). Espacialização da cobertura do serviço de saneamento básico e do índice de desenvolvimento humano dos municípios do Marajó, Pará. Revista Verde de Agroecologia e Desenvolvimento Sustentável, 11(4), 112-122. https://doi.org/10.18378/rvads.v11i4.4507

Dutra, F. M., Brazão, C. C., Heldt, A., \& Ballester, E. L. C. (2015). Carcinicultura: Relato de experiência no oeste do Paraná. Revista de Extensão do IFSC, 1(3), 117122.

http://dx.doi.org/10.35700/ca.2015.ano2n3. p117-122.1790

Fadel, C. B., Bordin, D., Kuhn, E., \& Martins, L. D. (2013). O impacto da extensão universitária sobre a formação acadêmica em Odontologia. Comunicação Saúde Educação, 17(47), 937-46. https://doi.org/10.1590/1807$\underline{57622013.3811}$

FAO. (2018). The State of World Fisheries and Aquaculture. Meeting the sustainable development goals. Rome. Retrieved: http://www.fao.org/3/i9540en/I9540EN.pd f. Access in: 28/10/2018.

Ferretti, C. J., Zibas, D. M. L., \& Tartuce, G. L. B. P. (2004). Protagonismo juvenil na literatura especializada e na reforma do ensino médio. Cadernos de Pesquisa, 34(122), 411-423. https://doi.org/10.1590/S0100$\underline{15742004000200007}$

Freire, C. E. C., \& Gonçalves, A. A. (2013). Diferentes métodos de abate do 
Silva, F. N. L., Mendonça, R. C., Quadros, M. L. A., Oliveira, L. C., Macedo, A. R. G., Silva, O. L. L., \& Oliveira, L. A. A. (2020). Students as promoters of rural extension in aquaculture in the Marajó archipelago, Pará, Brazil...

pescado produzido em aquicultura, qualidade da carne e bem estar do animal. Revista Holos,

6. https://doi.org/10.15628/holos.2013.992

Freire, P. (2001). Pedagogia do oprimido. 31. ed. Rio de Janeiro: Paz e Terra. Retrieved:

https://www.paulofreire.org/download/eadf reiriana/E-book_50_Olhares.pdf. Access in: 06/04/2020.

Garutti, V. (2003). Piscicultura ecológica. São Paulo: Unesp. Retrieved: http://livros01.livrosgratis.com.br/up00003 8.pdf. Access in: 06/04/2020.

Gonçalves, L. U., Cerozi, B. S., Silva, T. S. C., Zanon, R. B., \& Cyrino, J. E. P. (2015). Crude glycerin as dietary energy source for Nile tilapia. Aquaculture, 437, 230-234. https://doi.org/10.1016/j.aquaculture.2014. $\underline{12.004}$

IBGE. (2016). Instituto Brasileiro de Geografia e Estatística. Produção da Pecuária Municipal 2016. 44, Brasil. IBGE, Rio de Janeiro. Retrieved: https://biblioteca.ibge.gov.br/visualizacao/ periodicos/84/ppm_2016_v44_br.pdf.

Access in: 06/04/2020.

IBGE. (2010). Instituto Brasileiro de Geografia e Estatística. Censo Demográfico 2010. Resultados gerais da amostra. Rio de Janeiro: IBGE. Retrieved: https://biblioteca.ibge.gov.br/visualizacao/ periodicos/93/cd_2010_caracteristicas_pop ulacao_domicilios.pdf. Access in: 06/04/2020.

Joffre, O. M., De Vries, J. R., Klerkx, L., \& Poortvliet, P. M. (2020). Why are cluster farmers adopting more aquaculture technologies and practices? The role of trust and interaction within shrimp farmers' networks in the Mekong Delta, Vietnam. Aquaculture, 523. https://doi.org/10.1016/j.aquaculture.2020. $\underline{735181}$
Karim, M., Leemans, K., Akester, M., \& Phillips, M. (2019). Performance of emergent aquaculture technologies in Myanmar; challenges and opportunities. Aquaculture, 519. https://doi.org/10.1016/j.aquaculture.2019. $\underline{734875}$

Maciel, C. R., \& Valenti, W. C. (2014). Effect of tank colour on larval performance of the Amazon River prawn Macrobrachium amazonicum. Aquaculture Research, 45(6), 1041-1050. https://doi.org/10.1111/are.12048

Magnusson, W. E. (2003). Turtle management as scientific experimentation. Chelonian Conservation and Biology, 4(3), 722-723.

Manchur, J., Suriani, A. L. A., \& Cunha, M. C. D. (2013). A contribuição de projetos de extensão na formação profissional de graduandos de licenciaturas. Revista Conexão UEPG, 9(2), 334-41. Retrieved: http://www.revistas2.uepg.br/index.php/co nexao. Access in: 06/04/2020.

Martins, S. N., Eckhardt, V. M. T., Valandro, N. A., \& Costa, J. (2015). A contribuição da extensão na formação de universitários: um estudo de caso. Revista NUPEM, 7(12). Retrieved: http://www.fecilcam.br/revista/index.php/n upem/article/view/502. Access in: 06/04/2020.

Mendes, E. G. (2010). Breve histórico da Educação Especial no Brasil. Revista Educación y Pedagogía, 22(57), 93-109. Retrieved:

file:///C:/Users/lyko_Downloads/9842Texto\%20de1\%20art_culo-28490-2-1020110810\%20(1).pdf. Access in: $06 / 04 / 2020$.

Mitre, S. M., Siqueira-Batista, R., GirardiDe-Mendonça, J. M., Morais-Pinto, N. M., 
Meirelles, C. A. B., Pinto-Porto, C., Moreira, T., \& Hoffmann, L. M. A. (2008). Metodologias ativas de ensinoaprendizagem na formação profissional em saúde: debates atuais. Ciências Saúde Coletiva [online], 13, 2133-2144. https://doi.org/10.1590/S1413-

\section{$\underline{81232008000900018}$}

O’ de Almeida Júnior, C. R. M., \& Souza, R. A. L. (2013). Aquicultura no Nordeste paraense, Amazônia Oriental, Brasil. Boletim Técnico Científico do Cepnor, 13(1), 33-42. http://dx.doi.org/10.32519/tjfas.v13i1.867

Obiero, K. O., Waidbacher, H., Nyawanda, B. O., Munguti, J. M., Manyala, J. O., \& Kaunda-Arara, B. (2019). Predicting uptake of aquaculture technologies among smallholder fish farmers in Kenya. Aquaculture International, 1689-1707 (2019). $\quad$ https://doi.org/10.1007/s10499019-00423-0

Oliveira, A. S. C., Souza, R. A. L., \& Melo, N. F. A. C. (2014). Estado da Arte da Piscicultura na mesorregião sudoeste paraense-Amazônia Oriental. Boletim Técnico Científico do Cepnor, 14(1), 3338.

http://dx.doi.org/10.32519/tjfas.v14i1.1784

Oliveira, G. R., Araújo, F. M., \& Queiroz, C. C. (2017). A Importância da assistência técnica e extensão rural (ATER) e do crédito rural para a agricultura familiar em Goiás. Boletim Goiano de Geografia, 37(3), 528-551. https://doi.org/10.5216/bgg.v37i3.50769

Pedrosa, J. I. S. (2007). Educação popular no Ministério da Saúde: identificando espaços e referências. In Brasil. Ministério da Saúde. Secretaria de Gestão Estratégica e Participativa. Departamento de Apoio à Gestão participativa. Caderno de educação popular e saúde. Brasília, DF: Ministério da Saúde, 13-17. Recuperado de: http://bvsms.saude.gov.br/bvs/publicacoes/ caderno_educacao_popular_saude_p1.pdf. Acesso em: 06/04/2020.

Pizzio, A., \& Milagres, C. S. F. (2019). Entre o discurso do reconhecimento e a prática da intervenção: a política nacional de assistência técnica e extensão rural como mecanismo de justiça social para a agricultura familiar. Revista Brasileira de Gestão e Desenvolvimento Regional, 15(2), 145-155. Retrieved: https://www.rbgdr.net/revista/index.php/rb gdr/article/view/4456/770. Access in: 06/04/2020.

PNUD, IPEA, F. (2013). Índice de Desenvolvimento Humano Municipal Brasileiro. Brasília: Programa das Nações Unidas para o Desenvolviento - PNUD. Retrieved:

http://ipea.gov.br/portal/index.php?option= com content\&id=19153. Access in: 06/04/2020.

Rodrigues, M., Ferreira, H., Figueira, D., Almeida, A. M. L., \& Oliveira, L. R. (2012). Memorial de escolas uma experiência entre o ensino, a pesquisa e a extensão. Revista Fluminense de Extensão Universitária, 2(2), 27-36. Retrieved: file:///C:/Users/lyko/Downloads/555-

Texto\%20do\%20artigo-991-1-1020161122\%20(1).pdf. Access in: 06/04/2020.

Rosário, C. L., Araújo, K. O., Ferreira, N. N., Mesquita, S. C. R., \& Santos, R. M. R. (2013). Indissociabilidade entre ensino, pesquisa e extensão universitária: experiências nos cursos de licenciatura do Instituto Federal de Roraima. In Anais... 10 Simpósio de Excelência em Gestão e Tecnologia, Roraima. Retrieved: https://www.aedb.br/seget/arquivos/artigos 13/56218703.pdf. Access in: 06/04/2020.

Santiago, J. L., \& Surís-Regueiro, J. C. (2018). An applied method for assessing socioeconomic impacts of European fisheries quota-based management. 
Silva, F. N. L., Mendonça, R. C., Quadros, M. L. A., Oliveira, L. C., Macedo, A. R. G., Silva, O. L. L., \& Oliveira, L. A. A. (2020). Students as promoters of rural extension in aquaculture in the Marajó archipelago, Pará, Brazil...

Fisheries Research, 206, 150-162. https://doi.org/10.1016/j.fishres.2018.05.01 $\underline{0}$

Silva, F. N. L. (2019). Tortas e óleos de buriti (Mauritia flexuosa), coco (Cocos nucifera) e dendê (Elaeis guineenses) em dietas para tambaqui (Colossoma macropomum Cuvier, 1818) (Tese de Doutorado). Universidade Federal do Pará, Belém.

Silva, F. N. L., \& Oliveira, L. C. (2020). Reflections on teaching aquaculture in the Marajó archipelago, Eastern Amazon. Revista Brasileira de Educação do Campo, 5 , e7893. http://dx.doi.org/10.20873/uft.rbec.e7893

Silva, K. R., Bergamasco, S. M. P. P., \& Souza-Esquerdo, V. F. (2018). Assistência Técnica e Extensão Rural no Vale do Ribeira Paranaense. Revista Brasileira de Desenvolvimento Regional, 6(2), 103-124. http://dx.doi.org/10.7867/2317-

5443.2018v6n2p103-124

Silva, L. E. N., Gomes Neto, M. B., \& Grangeiro, R. R. (2019). Projeto "Andanças Culturais": preservação da imagem de padre Cícero de Juazeiro do Norte, Ceará. Em Extensão, 18(1), 230242. $\quad$ https://doi.org/10.14393/REE$\underline{\mathrm{v} 18 \mathrm{n} 12019-45625}$

Silva, L. F. M. (2019). Assessoria executiva em arquivos: relato das percepções acadêmicas de um projeto de extensão universitária. Revista de Gestão e Secretariado, 10(1), 73-90. https://doi.org/10.7769/gesec.v10i1.792

Lameira Silva, O. L. L., Macedo, A. R. G., Nunes, E. S. C. L., Campos, K. D., Tiburco, X., Araujo, L. C. C., Pinto, A. S. O., Joele, M. R. S. P., Ferreira, M. S., Silva, A. C. R., Raices, R. S. L., Cruz, A. G., Juen, L., \& Rocha, R. M. (2020). Effect of environmental factors on the fatty acid profiles and physicochemical composition of oysters (Crassostrea gasar) in Amazon estuaries farming. Aquaculture Research, xx, 1-13. https://doi.org/10.1111/are.14577

Sonzogno, M. C., Moreno, L. R., \& Abensur, P. L. D. (2013). Educação em Saúde: implicações teóricasmetodológicas. In Silva, G. T. R. (Org.). Residência Multiprofissional em Saúde: vivências e cenários da formação (pp. 116). São Paulo: Martinari.

Stéfani, M. V., Pereira, M. M., Reche, M. R., \& Mansano, C. F. M. (2015). Fecal collection methods for the determination of protein digestibility in bullfrogs. Ciência Rural, 45(8). https://doi.org/10.1590/0103$\underline{8478 \mathrm{cr} 20141369}$

Suplicy, F. M., Vianna, L. F. N., Rupp, G. S., Novaes, A. L. T., Garbossa, L. H. P., Souza, R. V., Guzenski, J., Costa, S. W., Silva, F. M., \& Santos, A. A. (2015). Planning and management for sustainable coastal aquaculture development in Santa Catarina State, south Brazil. Reviews in Aquaculture, 9(2), 107-124. https://doi.org/10.1111/raq.12107

Tiago, G. G., \& Gianesella, S. M. F. (2003). O uso da água pela aqüicultura: estratégias e ferramentas de implementação de gestão. Boletim do Instituto de Pesca, 29(1), 1-7, 2003. Retrieved:

https://www.pesca.agricultura.sp.gov.br/Ti ago.PDF. Access in: 06/04/2020.

Tubino, J. (2008). Apresentação. In: Ostrensky, A.; Borghetti, J. R.; Soto, D. (Ed.). Aquicultura no Brasil o desafio é crescer. Brasília: Secretaria Especial de Aquicultura e Pesca da Presidência da República / FAO, 2008. p.1-27. Retrieved: https://gia.org.br/portal/produto/2299/.

Access in: 06/04/2020.

Volpato, M. P., Martins, J. T., Kreling, M. C. D., Karino, M. E., Galdino, M. J. Q., \& Trevisan, G. S. (2016). Atendimento ao 
Silva, F. N. L., Mendonça, R. C., Quadros, M. L. A., Oliveira, L. C., Macedo, A. R. G., Silva, O. L. L., \& Oliveira, L. A. A. (2020). Students as promoters of rural extension in aquaculture in the Marajo archipelago, Pará, Brazil...

Portador de Feridas Crônicas por meio da Extensão Universitária: relato de experiência. Interagir: Pensando a Extensão, $\quad 22, \quad 179-186$. https://doi.org/10.12957/interag.2016.1737 $\underline{2}$

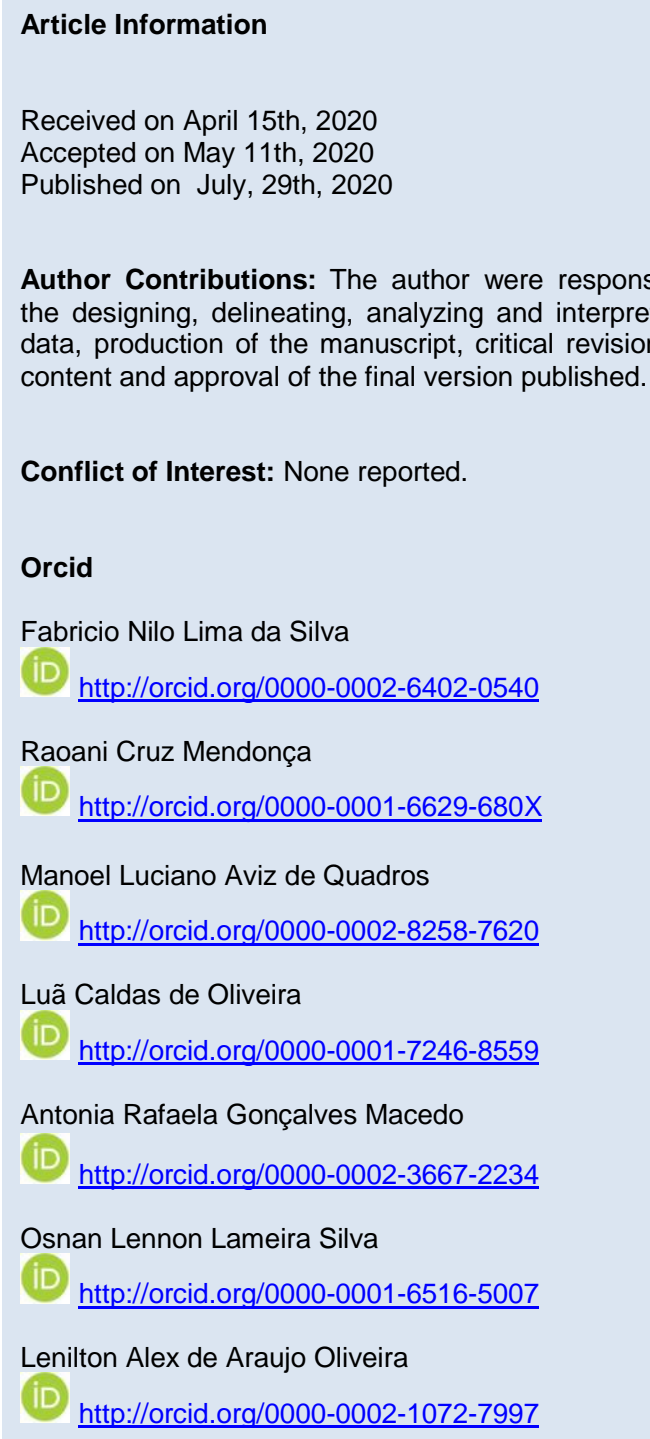
content and approval of the final version published.

Conflict of Interest: None reported.

Orcid

Fabricio Nilo Lima da Silva

(iD) http://orcid.org/0000-0002-6402-0540

Raoani Cruz Mendonça

(iD) http://orcid.org/0000-0001-6629-680X

Manoel Luciano Aviz de Quadros

(iD) http://orcid.org/0000-0002-8258-7620

Luã Caldas de Oliveira

iD http://orcid.org/0000-0001-7246-8559

Antonia Rafaela Gonçalves Macedo

(iD) http://orcid.org/0000-0002-3667-2234

Osnan Lennon Lameira Silva

iD http://orcid.org/0000-0001-6516-5007

Lenilton Alex de Araujo Oliveira

(iD)

http://orcid.org/0000-0002-1072-7997

Author Contributions: The author were responsible for the designing, delineating, analyzing and interpreting the data, production of the manuscript, critical revision of the

\section{How to cite this article}

APA

Silva, F. N. L., Mendonça, R. C., Quadros, M. L. A., Oliveira, L. C., Macedo, A. R. G., Silva, O. L. L., \& Oliveira, L. A. A. (2020). Students as promoters of rural extension in aquaculture in the Marajó archipelago, Pará, Brazil. Rev. Bras. Educ. Camp., 5, e8936. http://dx.doi.org/10.20873/uft.rbec.e8936

\section{ABNT}

SILVA, F. N. L.; MENDONÇA, R. C.; QUADROS, M. L. A.; OLIVEIRA, L. C.; MACEDO, A. R. G.; SILVA, O. L. L.;

OLIVEIRA, L. A. A. Students as promoters of rural extension in aquaculture in the Marajó archipelago, Pará Brazil. Rev. Bras. Educ. Camp., Tocantinópolis, v. 5, e8936, 2020. http://dx.doi.org/10.20873/uft.rbec.e8936 